\title{
Comparing Overhead versus Drip Irrigation for Production of Three Cultivars of Romaine Lettuce on Biodegradable Plastic Mulch
}

\author{
Jenny C. Moore ${ }^{1}$, Brian Leib ${ }^{2}$, Zachariah R. Hansen ${ }^{3}$, and \\ Annette L. Wszelakil ${ }^{1}$
}

Additional index words. cos lettuce, crop yield, disease, polyethylene mulch, soil exposure, sprinkler irrigation on risers

SuMmARY. Growers seeking alternatives to traditional polyethylene plastic mulch may use biodegradable plastic mulches (BDMs). However, plasticulture systems typically also use plastic drip tape underneath the mulch, which must be removed from the field and disposed of at the end of the season, making tilling the BDM into the soil more difficult and expensive. A potential solution to this dilemma may be to use other irrigation methods, such as overhead sprinklers, that could be more easily removed from the field and reused from year to year. At Knoxville, TN, in 2019 and 2020, we grew three cultivars of romaine lettuce (Lactuca sativa) on BDM with two irrigation systems (overhead sprinklers above the mulch and drip irrigation tape under the mulch) to compare water use, disease, and yield in these two irrigation systems. Water use was higher in overhead vs. drip irrigation in both years; however, the difference in water use was much smaller in 2019 due to higher rainfall amounts during the time period the lettuce was growing in the field (March to May). Disease incidence and severity were very low both years for both irrigation systems. There were no differences in marketable yield (number of heads) between irrigation treatment in 2019. In 2020, marketable yield by number was greater in the drip vs. overhead irrigation treatment. Unmarketable yield in 2019 was due to heads that were too small; in 2020 , unmarketability was predominantly due to tipburn in overhead irrigated 'Jericho'. Overall, marketable lettuce yield did not differ between irrigation treatments in 2019 and was similar for 'Parris Island Cos' in 2020. Although quantitative weed counts were not made, observations of weed pressure between rows showed that weed pressure was higher in overhead irrigated compared with drip irrigated subplots. This highlights the need to have a between-row weed management program in place. The results of this study suggest that with attention to cultivar and weed management, overhead irrigation could be a viable alternative to drip irrigation for lettuce production on BDM, especially for early spring lettuce when rainfall is historically more plentiful.

$\mathrm{T}$ he numerous benefits of polyethylene (PE) mulch for specialty crop production of many crops have been well established, such as weed control, moisture regulation, reduced disease, and higher quality and yield (Gao et al., 2019; Kasirajan and Ngouajio, 2012; Lamont, 2005). The environmental drawbacks of PE mulch, such as mulch disposal issues and plastic pollution, are also well established (Gao et al., 2019; Geyer et al., 2017; Steinmetz et al., 2016). BDMs have been shown to be a viable alternative, providing similar crop yields compared with PE mulch (Ghimire et al., 2018; Moore and Wszelaki, 2019; Tofanelli and Wortman, 2020 ), with the benefit of being able to be tilled into the soil at the end of the season. When used in conventional fields, a benefit of BDM is not having to remove it at the end of the season. If BDM is used on U.S. Department of Agriculture (USDA)certified organic land, however, it must be completely removed from the field or jeopardize the farm's certification in most cases. Certified organic growers also should be aware that while the National Organic Program added BDMs to the list of allowable substances for organic production in 2014 , one of several caveats for its use is that only BDMs that are $100 \%$ biobased are allowed. As of this writing, there are no plastic BDMs commercially available that meet this requirement because most are $10 \%$ to $20 \%$ biobased (personal communications with representatives from Novamont, Shelton, CT, and BASF, Florham Park, NJ]. One notable reason for this lower percentage of biobased ingredients in commercial products is that the biobased ingredients tend to be more brittle, resulting in tearing during machine laying.

Nonetheless, the components of BDMs have been shown to break down into carbon dioxide, water, and microbial biomass in soil under controlled laboratory conditions. Various BDMs have been shown to degrade after soil incorporation in the field; yet following breakdown in the soil to completion warrants further investigation (Ghimire et al., 2020). Still, plasticulture systems typically use drip irrigation under the mulch, which aids in conserving moisture and reducing disease pressure in these systems. However, using drip tape is cited by growers as an impediment to BDM adoption (personal communications with growers during extension meetings) because the plastic drip tape must be removed from the field before the BDM can be tilled in, and then the drip tape must be disposed of, which reduces the convenience and environmental benefits of using BDMs. Although the idea of biodegradable drip irrigation has been

\begin{tabular}{llll}
\hline $\begin{array}{l}\text { Units } \\
\text { To convert U.S. to SI, } \\
\text { multiply by }\end{array}$ & U.S. unit & SI unit & $\begin{array}{l}\text { To convert SI to U.S., } \\
\text { multiply by }\end{array}$ \\
\hline 0.4047 & acre $(\mathrm{s})$ & $\mathrm{ha}$ & 2.4711 \\
0.3048 & $\mathrm{ft}$ & $\mathrm{m}$ & 3.2808 \\
0.0929 & $\mathrm{ft}^{2}$ & $\mathrm{~m}^{2}$ & 10.7639 \\
3.7854 & gal & $\mathrm{L}$ & 0.2642 \\
2.54 & inch(es) & $\mathrm{cm}$ & 0.3937 \\
25.4 & inch(es) & $\mathrm{mm}$ & 0.0394 \\
0.4536 & $\mathrm{lb}$ & $\mathrm{kg}$ & 2.2046 \\
1.1209 & $\mathrm{lb} / \mathrm{acre}$ & $\mathrm{kg} \cdot \mathrm{ha}^{-1}$ & 0.8922 \\
0.0254 & $\mathrm{mil}(\mathrm{s})$ & $\mathrm{mm}$ & 39.3701 \\
6.8948 & $\mathrm{psi}$ & $\mathrm{kPa}$ & 0.1450 \\
$\left({ }^{\circ} \mathrm{F}-32\right) \div 1.8$ & ${ }^{\circ} \mathrm{F}$ & ${ }^{\circ} \mathrm{C}$ & $\left({ }^{\circ} \mathrm{C} \times 1.8\right)+32$
\end{tabular}


explored (Martin-Closas and Pelacho, 2011), we do not know of any products that are commercially available at the time of this writing. Another solution could be to use overhead irrigation instead of drip irrigation, which has been done successfully on farms in Spain (L. Martin-Closas, personal communication). Overhead irrigation systems for possible use with BDM include center pivot, linear move, traveling guns, side-rolls, and sprinklers on risers that are permanently installed underground or temporarily installed aboveground. The temporary sprinklers with risers used in some locations remain in place for the entire growing season but are portable, as well as reusable, and can be moved to another field the following year (Hoffman et al., 2007).

Lettuce (Lactuca sativa) is an important specialty crop for U.S. growers with head, leaf, and romaine lettuces having total crop values of $\$ 1.96$ billion, $\$ 650$ million, and $\$ 881$ million in 2019 , respectively (USDA, National Agricultural Statistics Service, 2020). One commonly seen benefit of growing lettuce in a plasticulture system with drip irrigation is reduced disease pressure; however, the relationship between disease and

\begin{abstract}
Received for publication 12 July 2021. Accepted for publication 27 Oct. 2021

Published online 10 January 2022

${ }^{1}$ Department of Plant Sciences, University of Tennessee Institute of Agriculture, 2505 E.J. Chapman Drive, 112 PBB, Knoxville, TN 37996

${ }^{2}$ Department of Biosystems Engineering and Soil Science, University of Tennessee Institute of Agriculture, 2506 E.J. Chapman Drive, Knoxville, TN 37996

${ }^{3}$ Department of Entomology and Plant Pathology, University of Tennessee Institute of Agriculture, 2505 E.J. Chapman Drive, Knoxville, TN 37996

We thank colleague Samantha Flowers; graduate student Tim Siegenthaler; student workers Elgin Akin, Brianna Baxter, Jareth Beeler, Gavin Belfry, Sophia Bellamy, Malynn Berger, Ashley Coane, Zach Emery, Ashley Nelson, and Meghan Shemwell; East Tennessee AgResearch and Education Center farm crew members BJ DeLozier, Cody Fust, Bill Lively, Nick Tissot, and Charles Summey for invaluable help with field work; and Arnold Saxton for statistical advice. We are grateful for the financial support from the U.S. Department of Agriculture Specialty Crop Block Grant Program. Any opinions, findings, conclusions, or recommendations expressed in this article are those of the authors and do not necessarily reflect the view of the U.S. Department of Agriculture.
\end{abstract}

A.L.W. is the corresponding author. E-mail: annettew@utk.edu.

This is an open access article distributed under the CC BY-NC-ND license (https://creativecommons. org/licenses/by-nc-nd/4.0/).

https://doi.org/10.21273/HORTTECH04916-21 irrigation is complicated and depends on many factors such as crop, inoculum pressure, timing and method of irrigation, and environmental factors such as temperature and relative humidity (CaféFilho et al., 2019). Some lettuce diseases are worsened by increased leaf wetness. Examples include downy mildew (Bremia lactucae), bacterial leaf spot (Xanthomonas campestris pv. vitians), anthracnose (Microdochium panattonianum), and gray mold (Botrytis cinerea) (Koike et al., 2007). Other diseases, such as lettuce drop caused by Sclerotinia sclerotiorum and Sclerotinia minor, may be less affected by duration of leaf wetness because this disease can infect lettuce through direct soil contact (Subbarao et al., 2017). A study comparing field- and high-tunnel-grown lettuce in Georgia found that even though duration of leaf wetness was less for high tunnel lettuce, lettuce drop disease incidence was not different from lettuce grown in the field even when incidence was relatively high at about $20 \%$ (Jayalath et al., 2017). They also found that romaine lettuce transplanted earlier in the season had significantly more lettuce drop disease than lettuce transplanted later, indicating that other factors such as temperature may play a more significant role than leaf wetness for this particular disease. Similarly, another study comparing lettuce drop disease on three types of lettuce in Arizona and California found no difference in disease incidence when comparing sprinkler to furrow irrigation, but increased inoculum pressure did result in increased disease (Chitrampalam et al., 2010). Our objective was to compare the effects of drip and overhead irrigation systems on water use, yield, quality, and disease of three romaine lettuce cultivars grown using BDM.

\section{Materials and methods}

EXPERIMENTAL LOCATION AND DESIGN. This study was carried out in 2019 and 2020 at the University of Tennessee, East Tennessee AgResearch and Education Center, Organic Crops Unit (OCU) at Knoxville, TN (lat. $35.88^{\circ} \mathrm{N}$, long. $83.93^{\circ} \mathrm{W}$, elevation $886 \mathrm{ft}$ ). The OCU has 18 acres that are certified organic and 3 acres that are not certified. This study was conducted in a field that is not certified organic. The field site was located in the subtropical southeast United States with an average daily maximum temperature of $70.0{ }^{\circ} \mathrm{F}$, an average daily minimum temperature of $49.5^{\circ} \mathrm{F}$, and an average rainfall of 55.8 inches [30-year average (National Oceanic and Atmospheric Administration, National Centers for Environmental Information, 2020]. Soil type is Dewey silt loam with a $\mathrm{pH}$ of 6.4. This experiment was a randomized split-plot design with irrigation method as the main plot factor with two levels and cultivar as the subplot factor with three levels. Each cultivar was randomized within main plot blocks that were replicated four times. Each 5 -ft-long subplot (experimental unit) consisted of four raised beds ( 6 to 7 inches high and $2.5 \mathrm{ft}$ wide) with bed centers spaced $6 \mathrm{ft}$ apart. Each bed contained a staggered double row of lettuce spaced 12 inches between row and within row. There was a 10 - $\mathrm{ft}$ buffer separating drip from overhead plots to prevent mist from overhead plots reaching the drip plots (Fig. 1).

Planting and MUlCh LaYing. 'Coastal Star', 'Jericho', and 'Parris Island Cos' lettuce seeds (Johnny's Selected Seeds, Albion, ME) were sown in a greenhouse in 128-cell trays in potting media (PRO-MIX BXGeneral purpose; Premier Tech Ltd., Quakertown, PA) on 12 Feb. 2019. A second planting of all cultivars was sown on 14 Mar. 2019. In 2020, all cultivars were sown on 26 Feb.; however, due to field preparation and mulch laying delays from COVID-19, a second sowing of all cultivars occurred on 1 Apr. Preplant fertilizer $(400 \mathrm{lb} /$ acre of $10 \mathrm{~N}-4.4 \mathrm{P}-8.3 \mathrm{~K}$; Tennessee Farmers Cooperative, Knoxville, TN), providing $40 \mathrm{lb} /$ acre nitrogen $(\mathrm{N}), 17.6 \mathrm{lb} /$ acre phosphorus $(\mathrm{P})$, and $33.2 \mathrm{lb} /$ acre potassium $(\mathrm{K})$, was broadcast with a drop spreader over the plot area (6344 $\mathrm{ft}^{2}$ ) and incorporated with a springtooth harrow with rolling basket (Kongskilde Agriculture, Hudson, IL) both years. Black biodegradable plastic mulch (Organix A.G.; Organix Solutions, Maple Grove, MN) was laid by machine (model 2600 Bed Shaper; Rain-Flo Irrigation, East Pearl, $\mathrm{PA}$ ) in all plots at the time of bed shaping on 22 Mar. 2019 and 4 May 2020. Drip irrigation tape was laid simultaneously on the soil surface under the mulch in the drip plots. A sprinkler system was set up for the overhead irrigated plots. Both irrigation systems are described in more 
$122 \mathrm{ft}$

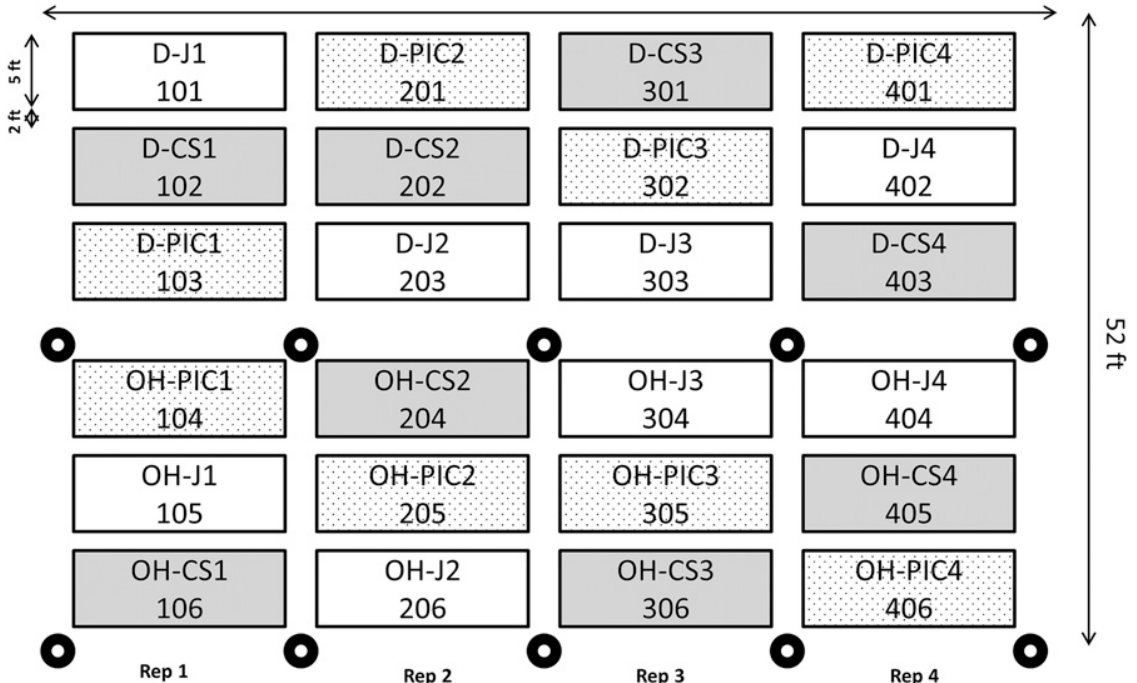

- Overhead

D= Drip irrigation

$\mathrm{OH}=$ Overhead irrigation

\section{J=Jericho}

CS=Coastal Star

PIC=Paris Island Cos

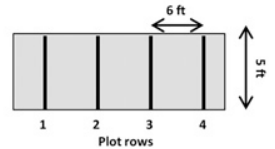

Fig. 1. Field diagram of lettuce irrigation trial at Knoxville, TN, in 2019 and 2020. Overhead irrigation was provided by sprinklers on risers and drip irrigation was provided by plastic tape under the mulch. Three cultivars of lettuce were grown, Coastal Star, Jericho, and Parris Island Cos; $1 \mathrm{ft}=0.3048 \mathrm{~m}$.

detail in the Irrigation section below. In 2019 , transplants of the three cultivars grew at different rates, therefore, Jericho was planted in the field first on 28 Mar. using the 12 Feb. sown seedlings (6-week-old seedlings), then Coastal Star and Parris Island Cos were planted in the field on 11 Apr. using the 14 Mar. sown seedlings (4-weekold seedlings). On 18 Apr. 2019, transplants that did not survive in the field were replanted using 14 Mar. sown seedlings for all cultivars. In 2020 , all cultivars of lettuce were planted on 15 May 2020 using the 1 Apr. sown transplants (6-week-old seedlings). Transplanting was done much later in the season in 2020 compared with 2019 due to constraints caused by the COVID-19 pandemic. One week after transplanting in 2020, any transplants that did not survive were replanted.

IRRIGATION. Drip irrigation was provided using plastic drip tape under the mulch $[5 / 8$ inch diameter, $8 \mathrm{mil}$ thickness, 8 inches emitter spacing, $0.34 \mathrm{gal} / \mathrm{min}$ flow per $100 \mathrm{ft}$ at $8 \mathrm{psi}$ (T-Tape 508-08-340; Rain-Flo Irrigation)]. The tapes were spaced $6 \mathrm{ft}$ apart (one in the center of each lettuce bed) with a 12 -psi pressure regulator [ 1 inch, 2-20 gal/min (Senninger, drip on-time was verified from pressure switch readings and the sprinkler on-time and amounts were verified by the rain gauge in that plot. Sprinkler irrigation events could easily be identified in this rain gauge by comparison with the drip rain gauge, which did not capture irrigation.

Sprinkler run times were much shorter than drip run times because drip has a much slower application rate than sprinklers even though less water was being applied by the drip system to wet the beds. Irrigation in both systems was monitored using soil matric potential sensors (MPS-2, METER Group), installed at 4- and 12 -inch depths in two locations, one in-row and one along the edge of the raised beds in all plots. The in-row sensors were buried in the beds in line with a row of lettuce, between the two lettuce plants, which allowed determination of soil moisture directly below the lettuce plants as it soaked across from the drip tape or entered planting holes via rainfall and sprinkler irrigation. The edge sensors were buried 3 inches from the outside edge of the raised bed to monitor moisture (rain and sprinkler irrigation) that soaked into the beds from the sides. All sensor data were logged (ZL6, METER Group) and could be viewed in near real-time via the internet (ZENTRA CLOUD, METER Group). In 2019, the first planting of lettuce (only 'Jericho') was hand watered, the amount of water used was not recorded, and soil sensors were not yet in place. All irrigation systems and sensors were in place by the time of planting the other two cultivars; therefore, water use for 2019 was calculated based on this planting date.

Disease Ratings. The center two beds of each subplot were scouted weekly for disease incidence from time of planting until harvest. White mold or lettuce drop was confirmed by visual observation of white mycelia near the base of plants showing wilt symptoms. The lettuce drop pathogen was not identified to the species level. Both $S$. sclerotiorum and $S$. minor can cause lettuce drop, although $S$. minor may be more common by infecting lettuce roots through eruptive germination of sclerotia (Heffer Link and Johnson, 2007). 
Harvest. The center two beds (each bed a double row) of lettuce were harvested at the mature head stage. There were typically 10 heads per bed (20 harvested per subplot total). In some cases, however, heads were lost to cutworms (Noctuidae) or other causes resulting in fewer than 20 heads harvested. In other cases, there were double heads, resulting in more than 20 heads harvested from the two center beds in a subplot. In 2019, 'Jericho' lettuce was harvested on 15 May, and 'Parris Island Cos' and 'Coastal Star' were harvested on 24 May. In 2020, all cultivars were harvested on 24 June. Heads were sorted into marketable and unmarketable (further sorted by primary reason for unmarketability) and all categories were counted and weighed. Marketability was determined according to USDA grade No. I specifications: "romaine plants of similar varietal characteristics which are fresh, well developed, well trimmed, and which are free from decay, and free from damage caused by seedstems, broken, bruised or discolored leaves, tipburn, wilting, foreign material, freezing, dirt, disease, insects, mechanical or other means" (USDA Agricultural Marketing Service, 2016). Head length, diameter, and core length were recorded for 10 marketable heads per subplot.

MULCH DETERIORATION RATINGS. The two center beds of each subplot were rated visually for mulch deterioration throughout the growing seasons. Ratings were made about twice per month, with four ratings in 2019 and two ratings in 2020. Ratings were conducted by the same person within a given season for consistency. Mulch deterioration was estimated as a percent of the soil that was exposed [percent soil exposure (PSE)] due to rips, tears or holes in the mulch, with $0 \%$ representing fully intact mulch and $100 \%$ representing fully exposed soil (Moore and Wszelaki, 2019).

Data analysis. All data were subjected to analysis of variance using generalized linear mixed model (GLIMMIX) procedure in SAS (version 9.4 for Windows; SAS Institute, Cary, NC). Data were analyzed as a split-plot design with completely randomized blocks. The MMAOV macro (Saxton, 2010) in SAS was used to build all PROC GLIMMIX procedures and the slice statement was used to simplify means comparison by dates. The assumption of normality was assessed using the Shapiro-Wilk test $(\mathrm{W}>0.80)$ and homogeneity of variances were assessed with Levene's test $(\alpha=0.05)$. Fisher's least significant difference test $(\alpha=0.05)$ was used to compare treatment means for significant differences. When interactions among treatments were significant, data were presented/explained separately for all treatment combinations. No transformation satisfied the assumptions of normality and homogeneity of variance for yield data, and thus a nonparametric transformation (PROC RANK in SAS) was used for mean separations; however, raw means are reported.

\section{Results}

IRRIGATION AND ENVIRONMENTAL CONDITIONS. Irrigation scheduling was primarily based on soil sensor data in 2019. In 2020, irrigation was scheduled based on a combination of soil sensors and farm crew evaluations (data not shown). In 2020, soil matric potential sensor readings indicated that soil was drying, while the farm maintenance crew found the plots to be moist by a finger-feel test. This problem was compounded by pandemic restrictions on personnel. Also, there were different rates of soil drying between overhead and drip irrigated plots (data not shown). This was partly because it was not possible to keep sensor levels identical because water enters the beds at different locations (on top of the bed under the mulch for drip vs. through planting holes and/or wicked from row middles under the mulch at the mulchsoil union for overhead) and different rates via the two irrigation methods. Precipitation early in the 2019 season reduced the need for irrigation in

Table 1. Precipitation and water applied by overhead and drip irrigation (inches) during the lettuce production seasons ["total water use" columns are the sum of all rainfall and irrigation events between planting dates and harvest dates (Apr. 11 to 24 May 2019 and May 15 to 24 June 2020)] at Knoxville, TN.

\begin{tabular}{|c|c|c|c|c|c|}
\hline & Precipitation & $\begin{array}{l}\text { Overhead } \\
\text { irrigation }\end{array}$ & $\begin{array}{c}\text { Drip } \\
\text { irrigation }\end{array}$ & $\begin{array}{c}\text { Overhead irrigated } \\
\text { plots total water } \\
\text { use }\end{array}$ & $\begin{array}{c}\text { Drip irrigated } \\
\text { plots total } \\
\text { water use } \\
\end{array}$ \\
\hline Yr & \multicolumn{5}{|c|}{ (inches) $^{\mathrm{z}}$} \\
\hline $2019^{y}$ & 6.0 & 3.3 & 1.9 & 9.3 & 7.9 \\
\hline 2020 & 1.8 & 11.4 & 4.3 & 13.2 & 6.1 \\
\hline
\end{tabular}

both treatments (Table 1). When examined as a percent increase in total water use (precipitation + irrigation) in 2019, we applied nearly double the amount of irrigation water in overhead plots, but this was only an $18 \%$ increase in total water use compared with drip irrigated plots. In 2020, when precipitation was much lower, total water use in overhead irrigated plots was 116\% higher compared with drip irrigated plots (Table 1). Maximum and minimum temperatures were higher over the 2020 growing season compared with 2019 (Fig. 2), increasing the need for irrigation.

LETTUCE YIELD BY NUMBER OF HEADS-MARKETABLE AND UNMARKETABLE. Marketable yield did not differ among cultivars or irrigation treatments in 2019; however, irrigation and cultivar had significant effects on marketable and unmarketable yield in 2020 (Table $2)$. Irrigation $\times$ cultivar interactions were significant for marketable yield in 2020 and for unmarketable yield both years (Table 2). In 2020, marketable yield was higher for drip irrigated Coastal Star compared with drip irrigated Jericho and all cultivars in overhead irrigated plots (Table 3). Also, marketable yield for drip irrigated 'Jericho' was higher than overhead irrigated 'Jericho' (Table 3). Overhead irrigated 'Jericho' had the highest unmarketable yield compared with all other cultivars and irrigation treatments (Table 3).

LETTUCE YIELD BY NUMBER OF HEADS-REASONS FOR UNMARKETABILITY AND DISEASE OBSERVATIONS. The primary causes for unmarketability were tipburn, small head size, and bolting. The number of heads that bolted was very low, and there were no significant differences among cultivars or 


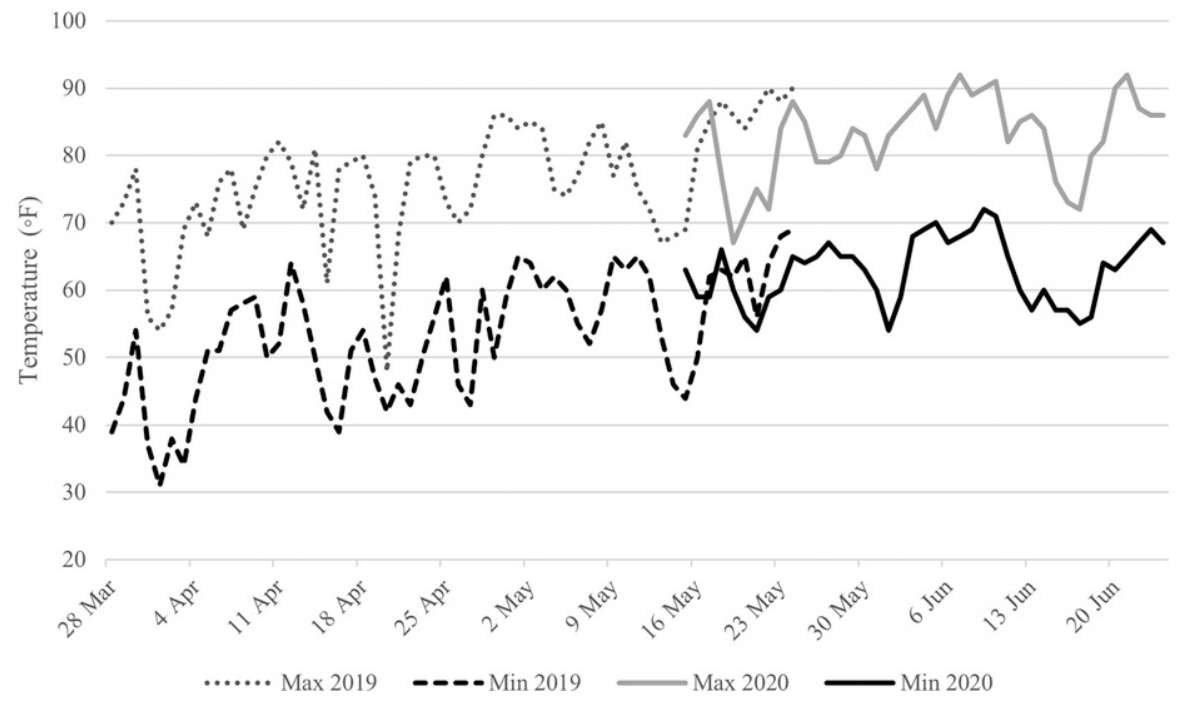

Fig. 2. Daily maximum and minimum temperatures during the 2019 and 2020 lettuce irrigation trial at Knoxville, TN. Overhead irrigation was provided by sprinklers on risers and drip irrigation was provided by plastic tape under the mulch. Three cultivars of lettuce were grown: Coastal Star, Jericho, and Parris Island Cos; $\left({ }^{\circ} \mathrm{F}-32\right) \div 1.8={ }^{\circ} \mathrm{C}$.

irrigation treatments (data not shown). Irrigation treatment, cultivar, and irrigation $\times$ cultivar interaction were all significant for tipburn in 2020 but not in 2019 (Table 2). Overhead irrigated 'Jericho' in 2020 had higher rates of tipburn (mean number of heads) compared with all other cultivars and irrigation treatments (Table 3 ). Both drip (2.3 heads) and overhead ( 2.5 heads) irrigated 'Jericho' had higher numbers of heads that were too small in 2019 $(P=0.033)$; however, this difference was not seen in 2020 (data not shown). Disease levels were very low in both years. White mold incidence was $2.5 \%$ or less overall. There were no significant differences in white mold incidence among treatments in 2019 or 2020 (data not shown). No other lettuce diseases were observed during the trials.

LETTUCE YIELD-HEAD SIZE. Irrigation treatment, cultivar, and irrigation $\times$ cultivar interaction were significant for head length in 2019 and 2020 (Table 2). Irrigation treatment was not significant for lettuce head diameter, core length, or individual head weight in either year, with the exception of core length in 2020 (Table 2). Cultivar had significant effects on lettuce head diameter, core length, and individual head weight in both years, with the exception of diameter and head weight in 2020 (Table 2). Irrigation $\times$ cultivar interaction was not significant for diameter, core length, or head weight in either year, except for diameter in 2019 and core length in 2020 (Table 2). Head measurement data show the variability in head size from 2019 to 2020 (Table 4). Drip irrigated 'Coastal Star' and 'Jericho' had longer heads in 2019. In 2020, drip and overhead 'Coastal Star' and 'Jericho' did not differ in head length, but overhead 'Parris Island Cos' had longer heads than drip irrigated 'Parris Island Cos' (Table 4). There were no differences in core length in 2019; however, in 2020 , overhead irrigated 'Jericho' had longer core lengths than any other cultivar and irrigation treatment combination (Table 4 ).

MulCh DETERIORATION RATINGS. Mulch remained intact over the growing season in both years. Primary reasons for rips and tears in the mulch were due to small holes made while inserting soil sensors. By the final rating time in both years, PSE was still very low [ $1 \%$ to $3 \%$ in 2019 and $1 \%$ to $1.5 \%$ in 2020 (data not shown)].

\section{Discussion}

Irrigation treatment and cultivar did not have an effect on lettuce yield in 2019. Both of these factors affected yield in 2020 . This may be due in part to the difference in planting date (late Mar. to mid-Apr. 2019 vs. mid-May 2020). Additionally, rainfall was higher in 2019, and therefore, little irrigation was needed, reducing any potential

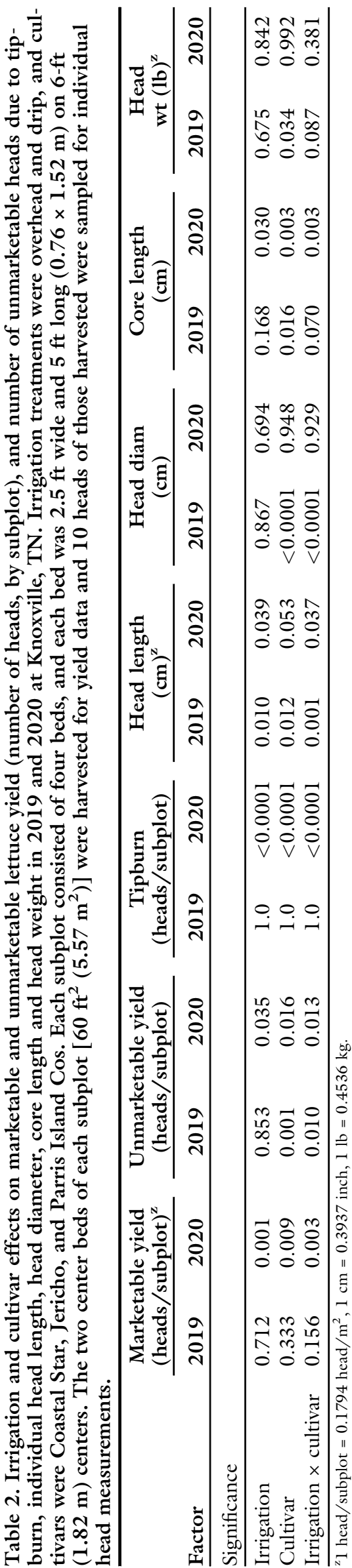


Table 3. Mean marketable and unmarketable lettuce yield by cultivar and irrigation treatment (number of heads per subplot) in 2019 and 2020 at Knoxville, TN. Each subplot consisted of four beds, each bed was $2.5 \mathrm{ft}$ wide and $5 \mathrm{ft}$ long $(0.76 \times 1.52 \mathrm{~m})$ on $6-\mathrm{ft}(1.82-\mathrm{m})$ centers. The two center beds of each subplot $\left[60 \mathrm{ft}^{2}\left(5.57 \mathrm{~m}^{2}\right)\right]$ were harvested for yield data. ${ }^{\mathrm{z}}$

\begin{tabular}{|c|c|c|c|c|c|}
\hline \multirow[b]{2}{*}{ Irrigation, cultivar } & \multicolumn{2}{|c|}{ Marketable yield (heads/subplot) ${ }^{\mathrm{y}}$} & \multicolumn{2}{|c|}{ Unmarketable yield (heads/subplot) } & \multirow{2}{*}{$\begin{array}{c}\text { Tipburn (heads/subplot) } \\
2020^{\mathrm{x}}\end{array}$} \\
\hline & 2019 & 2020 & 2019 & 2020 & \\
\hline Drip, Coastal Star & 18.5 & $19.8 \mathrm{a}^{\mathrm{w}}$ & $0.5 \mathrm{~b}$ & $0.3 \mathrm{c}$ & $0.0 \mathrm{c}$ \\
\hline Drip, Parris Island & 19.3 & $19.3 \mathrm{ab}$ & $0.5 \mathrm{~b}$ & $1.5 \mathrm{bc}$ & $0.0 \mathrm{c}$ \\
\hline Overhead, Coastal Star & 19.3 & $17.8 \mathrm{~b}$ & $0.3 \mathrm{~b}$ & $2.3 \mathrm{~b}$ & $0.3 \mathrm{~b}$ \\
\hline Overhead, Jericho & 17.3 & $13.3 \mathrm{c}$ & $2.5 \mathrm{a}$ & $7.0 \mathrm{a}$ & $4.8 \mathrm{a}$ \\
\hline
\end{tabular}

${ }^{\mathrm{z}}$ Most beds contained 10 heads of lettuce, resulting in 20 heads harvested per subplot; however, due to losses (primarily from cutworms) and some double heads, some plots may have more or less than 20 heads harvested total.

${ }_{1}^{\mathrm{y}} 1$ head $/$ subplot $=0.1794$ head $/ \mathrm{m}^{2}$.

${ }^{\mathrm{x}}$ No tipburn occurred in 2019.

${ }^{\text {w}}$ Treatment means with the same letter within a given column are not significantly different (Fisher's least significant difference at $\alpha=0.05$ ). Mean separation letters are taken from the transformed analysis; however, raw means are reported.

impact of irrigation treatment. For the cultivars Coastal Star and Jericho, there were more marketable heads in drip compared with overhead-irrigated plots in 2020, indicating that water application and availability affected yield. Moreover, because of the later planting date, temperatures were higher during the 2020 growing season, causing less-than-ideal growing conditions, which resulted in smaller, lighter heads. Also, core lengths were elongated in 2020, indicating that bolting was imminent, which was likely due to delayed planting date, and warmer air and soil temperatures. Similarly, in trials of six cultivars over 3 years, Dufault et al. (2006) reported that climatic conditions of a given year were a significant cause of fluctuations in head weight and length.

The main cause of unmarketable yield in 2019 was inadequate size. This may have been partly due to differences in planting dates on account of replanting from cutworm losses. In 2020, unmarketability was predominantly due to tipburn in overhead irrigated 'Jericho'. Cultivars vary in their susceptibility to tipburn, as we saw here with Jericho being the most affected. Tipburn is related to calcium (Ca) deficiency in actively growing leaves (Olle and Bender, 2009; Saure, 1998). Water stress interfering with Ca transport is often a cause, rather than low soil Ca levels (Koike and Turini, 2017). In a review of tipburn research, Olle and Bender (2009) reported that keeping soil moisture even and avoiding temperature extremes are vital for preventing tipburn. Although more water overall was used in the overhead treatment, less water may have been available under the BDM for the lettuce to transport calcium because of hotter temperatures during the 2020 grow- ing season (Fig. 2). Also, tipburn is more common during higher light intensities and longer photoperiods, as reported in Saure (1998). Our results reconfirm this, as temperatures were hotter and daylight hours longer due to planting 1 month later in 2020, compared with 2019, which was outside the recommended lettuce-planting window for this region. Planting date has a large influence on days to maturity and quality for lettuce (Dufault et al., 2006). With the later planting date in 2020, using a white-colored mulch may have resulted in better lettuce yield and quality by cooling the soil; however, white mulch may increase light intensity, which may exacerbate tipburn (Sago, 2016).

There are drawbacks to using overhead irrigation. One potential drawback could be increased disease. Yet in this study, we did not observe

Table 4. Mean individual lettuce head length, diameter (at widest point), core length, and head weight by cultivar and irrigation treatment (by subplot) in 2019 and 2020 at Knoxville, TN. Each subplot consisted of four beds, each bed was 2.5 $\mathrm{ft}$ wide and $5 \mathrm{ft}$ long $(0.76 \times 1.52 \mathrm{~m})$ on $6-\mathrm{ft}(1.82-\mathrm{m})$ centers. The two center beds of each subplot $\left[60 \mathrm{ft}^{2}\left(5.57 \mathrm{~m}^{2}\right)\right]$ were harvested for yield data, and 10 marketable heads of those harvested were sampled for individual measurements.

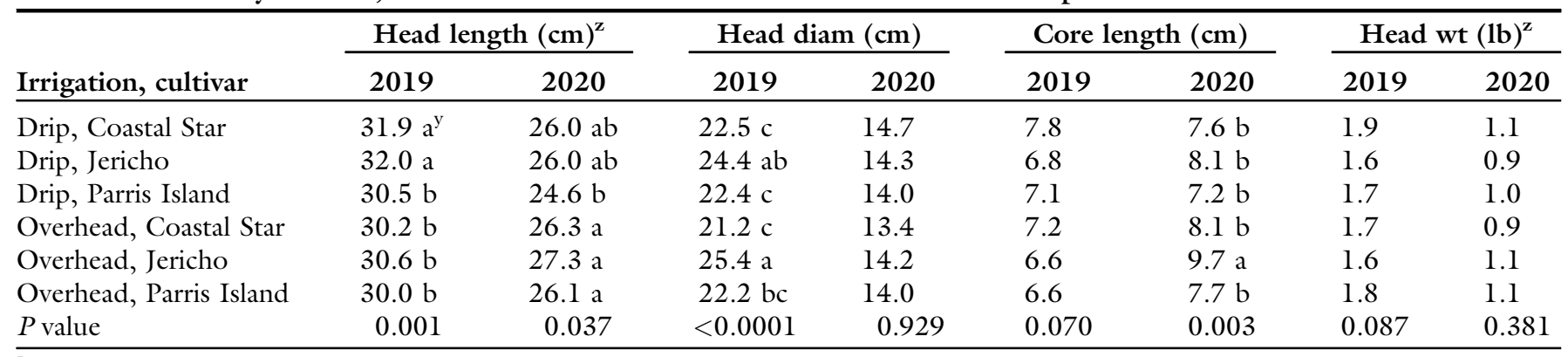

${ }^{\mathrm{z}} 1 \mathrm{~cm}=0.3937$ inch; $1 \mathrm{lb}=0.4536 \mathrm{~kg}$.

${ }^{\mathrm{y}}$ Treatment means with the same letter within a given column are not significantly different (Fisher's least significant difference at $\alpha=0.05$ ). Mean separation letters are taken from the transformed analysis; however, raw means are reported. 
increased disease pressure either year in overhead compared with drip plots (although, disease pressure was low overall in both systems). Additionally, overhead irrigation has been linked to higher contamination levels of bacteria, such as Escherichia coli, which can cause foodborne illness outbreaks, compared with drip irrigation (Fonseca et al., 2011). We did not test the water or lettuce for bacteria that cause foodborne illnesses in this study; however, we used municipal water for irrigation. Growers should be aware of this possibility, depending on the source of their irrigation water. Surface water sources (ponds, streams, rivers, etc.) are the highest risk, groundwater is of moderate risk, and municipal water is the lowest risk option. Another obstacle with overhead irrigation is increased water availability to weeds between beds. Although we did not formally quantify differences in weed pressure in this study, we did observe that weed pressure was greater in the overhead irrigated plots compared with the drip irrigated plots in 2020. Growers should have a between-row weed management plan in place, especially if they are considering overhead irrigation. Lastly, a concern with overhead irrigation is the increased water use and potential runoff. Several studies have shown that drip irrigation conserves water and reduces runoff compared with sprinkler or furrow irrigation (Darwish et al., 2003; Hansona et al., 1997). In agreement with these studies, we found that water use was higher in overhead plots, especially in 2020, when there was lower rainfall and higher air temperatures.

One drawback of BDMs, depending on location and climate, is early breakdown of the mulch before the end of the season. We thought that drip irrigated beds might have more rapid mulch deterioration due to the friction of the drip tape rubbing under the mulch, as we have seen in other studies (e.g., Ghimire et al., 2018). It is also conceivable that overhead irrigation could cause the mulch to deteriorate more rapidly. We found that the BDM used in this study stayed intact with both irrigation treatments. PSE ratings were less than $2 \%$ both years at the end of the season. One reason for this may be the short growing season for lettuce. With harvest occurring about 2 months after mulch laying, it is not surprising that the BDM stayed intact. Growers may have to contend with more mulch degradation for longer season crops, depending on their environmental conditions.

If considering BDM use, growers should carefully weigh their options for irrigation on the farm, considering their water source, crop, disease pressure, weed management options, crop water needs, and average annual rainfall and temperature. In years or geographic locations with high precipitation, an added benefit of overhead irrigation is that growers could avoid irrigation costs altogether, as overhead irrigation does not need to be installed in the field unless it is needed. Conversely, drip irrigation requires upfront costs because drip tape is generally installed at the beginning of the season simultaneously with laying mulch. In conclusion, marketable lettuce yield did not differ among irrigation treatments in 2019, and was similar for 'Parris Island Cos' in 2020. Additionally, disease incidence did not differ between irrigation treatments. This demonstrates that using overhead irrigation with BDM could be a viable option for lettuce, with careful cultivar selection and management.

\section{Literature cited}

Café-Filho, A.C., C.A. Lopes, and M. Rossato. 2019. Management of plant disease epidemics with irrigation practices. Irr. Agro-ecosyst. 123-141, https://doi. org/10.5772/intechopen.78253.

Chitrampalam, P., T.A. Turini, M.E. Matheron, and B.M. Pryor. 2010. Effect of sclerotium density and irrigation on disease incidence and on efficacy of Coniothyrium minitans in suppressing lettuce drop caused by Sclerotinia sclerotiorum. Plant Dis. 94:1118-1124, https://doi. org/10.1094/PDIS-94-9-1118.

Darwish, T., T. Atallah, S. Hajhasan, and A. Chranek. 2003. Management of nitrogen by fertigation of potato in Lebanon. Nutr. Cycl. Agroecosyst. 67:1-11, https:// doi.org/10.1023/A:1025107202143.

Dufault, R.J., B. Ward, and R.L. Hassell. 2006. Planting date and romaine lettuce cultivar affect quality and productivity. HortScience 41:640-645, https://doi. org/10.21273/HORTSCI.41.3.640.

Fonseca, J.M., S.D. Fallon, C.A. Sanchez, and K.D. Nolte. 2011. Escherichia coli survival in lettuce fields following its introduction through different irrigation systems. J.
Appl. Microbiol. 110:893-902, https://doi. org/10.1111/j.1365-2672.2011.04942.x.

Gao, H., C. Yan, Q. Liu, W. Ding, B. Chen, and Z. Li. 2019. Effects of plastic mulching and plastic residue on agricultural production: A meta-analysis. Sci. Total Environ. 651:484 492, https://doi.org/ 10.1016/j.scitotenv.2018.09.105.

Geyer, R., J.R. Jambeck, and K.L. Law. 2017. Production, use, and fate of all plastics ever made. Sci. Adv. 3(7):e1700782, https://doi.org/10.1126/sciadv.1700782.

Ghimire, S., M. Flury, E.J. Scheenstra, and C.A. Miles. 2020. Sampling and degradation of biodegradable plastic and paper mulches in field after tillage incorporation. Sci. Total Environ. 703, https://doi.org/ 10.1016/j.scitotenv.2019.135577.

Ghimire, S., A.L. Wszelaki, J.C. Moore, D.A. Inglis, and C. Miles. 2018. The use of biodegradable mulches in pie pumpkin crop production in two diverse climates. HortScience 53:288-294, https://doi. org/10.21273/HORTSCI12630-17.

Hansona, B.R., L.J. Schwankl, K.F. Schulbach, and G.S. Pettygrove. 1997. A comparison of furrow, surface drip, and subsurface drip irrigation on lettuce yield and applied water. Agr. Water Mgt. 33:139-157, https://doi.org/10.1016/ S0378-3774(96)01289-9.

Heffer Link, V. and K.B. Johnson. 2007. White mold. Amer. 10 Aug. 2021. <https://www.apsnet.org/edcenter/ disandpath/fungalasco/pdlessons/Pages / WhiteMold.aspx $>$.

Hoffman, G.J., R.G. Evans, M.E. Jensen, D.L. Martin, and R.L. Elliot. 2007. Design and operation of farm irrigation systems. 2nd ed. Amer. Soc. Agr. Biol. Eng., St. Joseph, MI.

Jayalath, T.C., G.E. Boyhan, E.L. Little, R.I. Tate, and S. O'Connell. 2017. High tunnel and field system comparison for spring organic lettuce production in Georgia. HortScience 52:1518-1524, https:// doi.org/10.21273/HORTSCI12284-17.

Kasirajan, S. and M. Ngouajio. 2012. Polyethylene and biodegradable mulches for agricultural applications: A review. Agron. Sustain. Dev. 32:501-529, https://doi. org/10.1007/s13593-011-0068-3.

Koike, S.T. and T.A. Turini. 2017. UC IPM pest management guidelines: Lettuce. Univ. Calif. Agr. Nat. Resour. Publ. 3450. 23 July 2020. < https://www2.ipm.ucanr. edu/agriculture/lettuce/Tipburn/>.

Koike, S.T., P. Gladders, and A.O. Paulus. 2007. Vegetable diseases-A color handbook. Academic Press, London, UK. 
Lamont, W. 2005. Plastics: Modifying the microclimate for the production of vegetable crops. HortTechnology 15:477-481, https://doi.org/10.21273/HORTTECH. 15.3.0477.

Martin-Closas, L. and A.M. Pelacho. 2011. Agronomic potential of biopolymer films, p. 277-334. In: D. Plackett (ed.). Biopolymers: New materials for sustainable films and coatings. Wiley, Hoboken, NJ.

Moore, J.C. and A.L. Wszelaki. 2019. The use of biodegradable mulches in pepper production in the southeastern United States. HortScience 54:1031-1038, https://doi. org/10.21273/HORTSCI13942-19.

National Oceanic and Atmospheric Administration, National Centers for Environmental Information. 2020. U.S. climate normals (1991-2020). Knoxville Experimental Station, TN. U.S. GHCND:U SC00404946. 8 Aug. 2021. <https://www.ncei.noaa. gov/access/us-climate-normals/\#dataset= normals-annualseasonal \& timeframe $=30 \&$ station $=$ USC00404946 $>$.
Olle, M. and I. Bender. 2009. Causes and control of calcium deficiency disorders in vegetables: A review. J. Hort. Sci. Biotechnol. 84:577-584, https://doi.org/ 10.1080/14620316.2009.11512568.

Sago, Y. 2016. Effects of light intensity and growth rate on tipburn development and leaf calcium concentration in butterhead lettuce. HortScience 51:1087-1091, https:// doi.org/10.21273/HORTSCI10668-16.

Saxton, A.M. 2010. DandA.sas: Design and analysis macro collection version 1.29. Univ. Tennessee, Knoxville.

Saure, M.C. 1998. Causes of the tipburn disorder in leaves of vegetables. Scientia Hort. 76:131-147, https://doi. org/10.1016/S0304-4238(98)00153-8.

Steinmetz, Z., C. Wollmann, M. Schaefer, C. Buchmann, J. David, J. Tröger, K. Muñoz, O. Frör, and G.E. Schaumann. 2016. Plastic mulching in agriculture. Trading short-term agronomic benefits for long-term soil degradation? Sci. Total
Environ. 550:690-705, https://doi.org/ 10.1016/j.scitotenv.2016.01.153.

Subbarao, K.V., R.M. Davis, and R.L. Gilbertson. 2017. Compendium of lettuce diseases. 2nd ed. Amer. Phytopathol. Soc., St. Paul, MN.

Tofanelli, M.B.D. and S.E. Wortman. 2020. Benchmarking the agronomic performance of biodegradable mulches against polyethylene mulch film: A metaanalysis. Agron. 10:1618, https://doi. org/10.3390/agronomy10101618.

U.S. Department of Agriculture, Agricultural Marketing Service. 2016. United States standards for grades of romaine. 17 Aug. 2021. <https://www.ams.usda.gov/sites/ default/files/media/RomaineStandard.pdf $>$.

U.S. Department of Agriculture, National Agricultural Statistics Service. February 2020. Vegetables 2019 summary. 13 Jan. 2021. <https://www.nass. usda.gov/Publications/Todays_Reports / reports/vegean20.pdf $>$. 